\title{
УПРАВЛЕНЧЕСКИЕ АСПЕКТЫ ФУНКЦИОНИРОВАНИЯ ГОСУДАРСТВЕННЫХ АКТИВОВ
}

\author{
С.С. Рябова*
}

Рассмотрены сущность и состав государственных активов, формирование которых связано с процессом преобразования государственных унитарных предприятий в открытые акционерные общества. Приведены типологизация и целевые установки создания государственных корпораций и национальных холдингов. Проанализирована система управления государственными пакетами акций на основе владельческого надзора в Республике Беларусь и обоснованы характерные особенности участия государства посредством его представителя в управлении акционерным обществом. Обобщен опыт Республики Казахстан в создании национальных холдингов и Российской Федерации в развитии корпоративных отношений и их влияния на экономику субъекта хозяйствования. Определены проблемы в системе управления государственными активами в Республике Беларусь и предложены способы их разрешения на основе зарубежного опыта.

Ключевые слова: владельческий надзор, государственные активы, государственные корпорации, корпоративное управление, национальный холдинг, государственный пакет акций, представитель государства.

JEL-классификация: H13, H82.

DOI: $10.46782 / 1818-4510-2020-3-47-57$

Материал поступил 10.06.2020 2.

Экономическое развитие страны в немалой степени зависит от государственной политики в сфере управления государственными активами. Их возникновению способствовали реформирование государственной собственности и приватизация, которые были обусловлены переходом к формированию рыночных отношений и созданию новых корпоративных структур. Эффективность управления государственными активами предопределяет устойчивое функционирование национальной экономики в целом. Данное положение вошло составной частью в Программу деятельности Правительства Республики Беларусь на 2016-2020 годы ${ }^{1}$, но к настоящему времени поставленные задачи не удалось реализовать в полной мере. В соответствии с этим повышение эффективности государственного сектора предусмотрено в проекте Ocновных направлений социально-экономи-

1 URL: http://www.government.by/upload/docs/ pdp2016_2020.pdf ческого развития Республики Беларусь на 2021-2025 годы. Наряду с этим разрабатывается законопроект о государственных организациях и хозяйственных обществах с участием государства.

Литературный обзор показал, что исследованиям теоретических, методологических и прикладных проблем работы государственного сектора и вопросов управления государственными активами занимались и занимаются многие отечественные и зарубежные ученые. Среди них: Л.И. Аверченко (2014), А.В. Бадирова (2012), И.В. Баранова (2014), В.И. Бельский (2018), Е.А. Бурибаев ${ }^{2}$ А. Запорожан (2008), М.М. Ковалев, С.Н. Румас, К.Ю. Юшко, М.Х. Шахуб (2018), В.П. Лященко (2001), О.А. Макарова. (2016), Д.А. Михайленко (2014), О.В. Осипенко (2016), Г. Ташкулова (2014) и др. Ими сформированы необходимые теоретические основы уп-

2 Бурибаев Е.А. Видовая характеристика государственных активов как объектов управления. URL: http:// www.rusnauka.com/3._KAND_2007/Pravo/18519.doc.htm

* Рябова Светлана Сергеевна (s-6093981@yandex.ru), доцент, кандидат экономических наук, Академия управления при Президенте Республики Беларусь (г. Минск, Беларусь). 
равления собственностью, концептуальные положения реформирования государственной собственности и приватизации. Представлена видовая характеристика государственных активов как объектов управления и выделены направления эффективного развития в различных отраслях экономики и др. Вместе с тем, подчеркивая значимость данных разработок, необходимо отметить, что актуальными остаются вопросы результативности управления государственными активами.

Целью данной статьи является исследование управленческих аспектов функционирования государственных активов и обоснование действенных мер по повышению их эффективности на основе зарубежного опыта.

Термин «государственные активы» часто употребим, понятен, но не закреплен в правовом поле Республики Беларусь. Рассмотрим содержание этого понятия. Государственная собственность, существовавшая при плановой экономике, в условиях становления рыночных отношений претерпевала трансформацию. Развитие рынка сопровождалось реформированием государственной собственности, которое в республике началось в 1991 г.

За период с 1991 по 2018 г. в стране было реформировано 5246 государственных предприятий республиканской и коммунальной формы собственности. Основным способом стало преобразование государственных унитарных предприятий в открытые акционерные общества, удельный вес которых составил $57 \%$ от общего числа реформированных предприятий. Данный подход был наиболее актуальным, так как предопределил возможность приватизации ${ }^{3}$.

После создания акционерного общества государство становилось его учредителем наравне с другими акционерами, получало пакет акций, величина которого зависела от стратегической значимости данной организации и наличия инвесторов. Таким образом, в Беларуси большинство государственных унитарных предприятий были преобразованы, а одним из их акционеров выступило государство. Это позво-

${ }^{3}$ URL: http://gki.gov.by/ru/activity_branches-estate-eref/ лило сформировать сегмент «акционерное общество с государственным участием».

В табл. 1 представлена информация по организациям Республики Беларусь в зависимости от организационно-правовой формы.

Наибольшее количество организаций приходится на общества с ограниченной ответственностью (далее - ООО), удельный вес которых с 2016 по 2019 г. вырос на 7,7 п. п. в общем числе организаций Республики Беларусь. Эта организационно-правовая форма является наиболее распространенной для вложения частного капитала. При этом в ООО может присутствовать и доля государства. Отмечается значительное количество унитарных предприятий, их доля в общем количестве по итогу 2019 г. составила 29,5\%. За последние четыре года она снизилась на 7,4 п. п. В качестве причин могут быть названы реформирование организаций государственной формы собственности и ликвидация организаций малого предпринимательства.

Количество акционерных обществ также имеет тенденцию к снижению, хотя и незначительную. По состоянию на 1 января 2020 г., в Республике Беларусь было 1844 акционерных общества с участием государства, при этом его доля колеблется от самой незначительной до стопроцентной ${ }^{4}$. Это обусловлено тем, что выделяются стратегические и функциональные субъекты хозяйствования, создающие и реализующие инфраструктурные проекты, социальные, коммерческие и др. ${ }^{5}$

В настоящее время преобразование государственных предприятий, подлежащих приватизации, в акционерные общества практически завершено, что позволило государству аккумулировать пакеты акций большинства таких структур. В контексте с этим стал использоваться термин «государственные активы». Государство может частично или полностью продавать свои пакеты акций и доли в обществах новому собственнику. Так происходит перераспре-

${ }^{4}$ По данным Государственного комитета по имуществу Республики Беларусь.

5 URL: http://www.pravo.by/novosti/obshchestvennopoliticheskie-i-v-oblasti-prava/2020/february/46848/ 


\begin{tabular}{|c|c|c|c|c|}
\hline \multirow[b]{2}{*}{ Форма организации } & 2016 г. & 2017 г. & 2018 г. & 2019 г. \\
\hline & \multicolumn{4}{|c|}{ Число организаций } \\
\hline $\begin{array}{l}\text { Всего юридических лиц } \\
\text { В том числе: }\end{array}$ & 141600 & 142610 & 141418 & 142108 \\
\hline $\begin{array}{l}\text { коммерческие организации } \\
\text { Из них: }\end{array}$ & 116190 & 116761 & 115256 & 115425 \\
\hline акционерные общества & 4001 & 4016 & 3782 & 3639 \\
\hline открытые акционерные общества & 2262 & 2301 & 2175 & 2118 \\
\hline закрытые акционерные общества & 1739 & 1715 & 1607 & 1521 \\
\hline общества с ограниченной ответственностью & 50371 & 54217 & 57462 & 61497 \\
\hline общества с дополнительной ответственностью & 6029 & 5685 & 5234 & 4878 \\
\hline унитарные предприятия & 52314 & 49468 & 45334 & 41946 \\
\hline $\begin{array}{l}\text { некоммерческие организации } \\
\text { Из них: }\end{array}$ & 25410 & 25849 & 26162 & 26683 \\
\hline потребительские кооперативы & 3330 & 3517 & 3629 & 3757 \\
\hline \multirow[t]{2}{*}{ учреждения } & 15032 & 14929 & 14744 & 14812 \\
\hline & \multicolumn{4}{|c|}{ \% к итогу } \\
\hline $\begin{array}{l}\text { Всего юридических лиц } \\
\text { В том числе: }\end{array}$ & 100,0 & 100,0 & 100,0 & 100,0 \\
\hline $\begin{array}{l}\text { коммерческие организации } \\
\text { Из них: }\end{array}$ & 82,1 & 81,9 & 81,5 & 81,2 \\
\hline акционерные общества & 2,8 & 2,8 & 2,7 & 2,6 \\
\hline открытые акционерные общества & 1,6 & 1,6 & 1,5 & 1,5 \\
\hline закрытые акционерные общества & 1,2 & 1,2 & 1,1 & 1,1 \\
\hline общества с ограниченной ответственностью & 35,6 & 38,0 & 40,6 & 43,3 \\
\hline общества с дополнительной ответственностью & 4,3 & 4,0 & 3,7 & 3,4 \\
\hline унитарные предприятия & 36,9 & 34,7 & 32,1 & 29,5 \\
\hline $\begin{array}{l}\text { некоммерческие организации } \\
\text { Из них: }\end{array}$ & 17,9 & 18,1 & 18,5 & 18,8 \\
\hline потребительские кооперативы & 2,4 & 2,5 & 2,6 & 2,6 \\
\hline учреждения & 10,6 & 10,5 & 10,4 & 10,4 \\
\hline
\end{tabular}

Источник. Статистический ежегодник Республики Беларусь. 2019: стат. сборник. Минск: Национальный статистический комитет Республики Беларусь. URL: https://www.belstat.gov.by/ofitsialnaya-statistika/publications/ izdania/index_14636

деление акционерного капитала между государственным сектором и частным.

Термин «государственные активы» применяется в Программе деятельности Правительства Республики Беларусь на 2016-2020 годы, предусматривающей создание Межведомственной координационной группы по вопросам повышения эффективности и реструктуризации государственных организаций, управления государственными активами ${ }^{6}$. Данная категория также используется в основных положениях проекта Основных направлений социально-экономического развития до 2025 года в части

${ }^{6}$ URL: http://www.government.by/upload/docs/ pdp2016_2020.pdf оценки эффективности управления государственными активами.

Выполненные нами исследования позволили установить, что термин «государственные активы» применяется в законодательстве Республики Казахстан. Так, в Бюджетном кодексе данной страны под государственными активами понимают имущественные, а также неимущественные права и блага, которые имеют стоимостную оценку и получены в собственность государства за средства проведенных ранее операций или событий ${ }^{7}$. Их состав определен в Программе управления государственны-

7 Бюджетный кодекс Республики Казахстан от 4 декабря 2008 года № 95-IV.URL: https://online.zakon.kz/ 
ми активами Республики Казахстан на 2006-2008 годы и включает активы государственных предприятий, активы государственных учреждений, государственные пакеты акций акционерных обществ, доли участия товариществ с ограниченной ответственностью8 $^{8}$ В то же время необходимо отметить, что механизм управления активами государственных предприятий и учреждений и механизм управления государственными пакетами акций и долями имеют существенные отличия, но по законодательству Казахстана находятся в государственной собственности.

Установлено, что в основе управления государственным унитарным предприятием лежит принцип ведомственной подчиненности. При этом распоряжение государственным имуществом находится в компетенции специального государственного органа управления. В Республике Беларусь - это Государственный комитет по имуществу Республики Беларусь.

Управление в акционерных обществах осуществляется согласно ст. 103 Гражданского кодекса Республики Беларусь. Высшим органом управления в акционерном обществе является общее собрание его акционеров, одним из которых является государство. Если в обществе более 50 акционеров, то создается совет директоров или наблюдательный совет ${ }^{10}$.

Управление государственными унитарными предприятиями и учреждениями основывается на принципах единоначалия и ведомственной подчиненности, а управления обществом - коллегиальности.

Государственные активы в виде пакетов акций в государственных компаниях и государственных корпорациях дают государству право прямого или косвенного управления данными организациями. Такой подход позволяет государству получать

\footnotetext{
8 URL: https://online.zakon.kz/

9 URL: http://www.pravo.by/document/?guid=3871\& $\mathrm{p} 0={ }_{\mathrm{v}} 19302103$

10 URL: http://www.pravo.by/document/?guid=3871 \&p $0=\mathrm{hk} 9800218$

11 Миренская М.В. 2003. Управление государственным пакетом акций в промышленности: автореф... дис. канд. экон. наук по специальности 08.00.05 - экономика и управление народным хозяйством. Москва: Российский государственный гуманитарный университет.
}

дивиденды и участвовать в управлении ${ }^{11}$, используя различные методы, которые принято классифицировать по определенным критериям (признакам) $)^{12}$.

В Республике Беларусь в настоящее время остро стоит проблема эффективного управления пакетами акций, находящимися в государственной собственности, которое основано на владельческом надзоре. Государственные пакеты акций акционерных обществ, созданных в процессе преобразования государственных унитарных предприятий, передаются в управление по отраслевому принципу. Соответственно ими управляют отраслевые органы (министерства, концерны, комитеты, в подчинении которых до преобразования в акционерные общества находились государственные унитарные предприятия).

За каждым акционерным обществом с участием государства закреплен отраслевой орган государственного управления, он и назначает представителя. Последние участвуют в работе органов управления акционерных обществ - общем собрании акционеров, совете директоров (наблюдательном совете). При этом голосовать представитель государства должен в соответствии с решением органа государственного управления, назначившего его.

Через систему владельческого надзора акционерные общества реализуют поставленные государством задачи. Количество представителей государства законодательно не регламентировано. Используя институт владельческого надзора, государство реализует функции как регулятора, так и собственника ${ }^{13}$.

Владельческий надзор был определен как система мер по участию государства в управ-

12 Признаки: по масштабам применения; отраслям и сферам применения; роли на различных этапах жизнедеятельности организации; степени опосредованности воздействия; уровню обобщения управленческих знаний и др. Брасс А.А. 2002. Менеджмент: основные понятия, видь, функции: учебное пособие. Минск: ООО «Мисанта»; Виханский О.С., Наумов А.И. 2003. Менеджмент: учебник. Москва: Экономистъ; Гончаров В.И. 2010. Менеджмент: учеб. пособие. Минск: Современная школа; Минцберг Г., Альстрэнд Б., Лэмнел Дж. 2001. Школь стратегий. Стратегическое сафари: экскурсия по дебрям стратегий менеджмента. СПб.: Питер.

13 Указ Президента Республики Беларусь от 19 февраля 2008 г. № $100 \ll О$ некоторых вопросах владельческого надзора». URL: http://www.pravo.by/upload/docs/op/ P31300074_1360616400.pdf 
лении обществами в целях повышения эффективности их деятельности и защиты экономических интересов государства. Однако в Беларуси такой подход на сегодняшний день не обеспечивает эффективной деятельности акционерных обществ. Это заключается, на наш взгляд, прежде всего в том, что представители государства назначаются часто из государственных служащих и не обладают специальными знаниями и высокой квалификацией в сфере финансов и менеджмента. Согласовательная мера голосования по вопросам повестки дня заседания Наблюдательного совета (Совета директоров) не всегда выполняется и в ряде случаев не учитывает экономические интересы общества.

В Республике Беларусь постепенно входит в практику институт корпоративного управления. Однако опыт его внедрения в деятельность белорусских акционерных обществ пока не дал положительных результатов.

Для оценки качества управления организациями с долей государственной собственности, являющейся государственными активами, рассмотрим экономические показатели их деятельности в Республике Беларусь (табл. 2). Так, в последние годы отмечается сокращение количества организаций с государственной долей (2016 г. - 1945, 2020 г. - 1584), что привело к уменьшению численности работников. Тренд увеличения номинальной заработной платы соответствовал проводимой государством социально-экономической политике. По состоянию на 1 апреля 2020 г. рост номинальной заработной платы составил 150\% к 2016 г.

За анализируемый период рентабельность продаж и рентабельность реализованной продукции сохраняются на уровнях $6,0-7,0 \%$ и $8,0-10,0 \%$ соответственно. В то же время наиболее результативным был 2017 г., когда организации с долей государственной собственности получили наибольшее значение данных показателей $(8,5 \%$ и 10,4\% соответственно). Чистая прибыль (убыток) характеризуется резким падением показателя в 2018 г. по сравнению с 2017 г. (в 7 раз), дальнейшим восстановлением в 2019 г. (рост на 48,0\% к 2017 г.) и убытками в январе-марте 2020 г.

По состоянию на 1 января 2020 г. уменьшилось количество убыточных организаций с долей государственной собственности, их удельный вес составил 15,8\% в общем количестве обследуемых организаций. В то же время изменение экономической ситуации в I квартале 2020 г., связанной с пандемией COVID-19, привело к росту убыточных организаций.

Для сравнения нами выполнен анализ эффективности функционирования органи-

Таблица 2

Основные экономические показатели деятельности организаций с долей государственной собственности, 2016-2020 гг.

\begin{tabular}{|c|c|c|c|c|c|c|}
\hline \multirow{2}{*}{ Показатель } & \multicolumn{4}{|c|}{ Год } & \multirow{2}{*}{$\begin{array}{c}\text { Январь-март } \\
2020 \text { г. }\end{array}$} & \multirow{2}{*}{$\begin{array}{c}2019 \text { г. } \\
\text { к уровню } \\
2016 \text { г., \% } \\
\end{array}$} \\
\hline & 2016 & 2017 & 2018 & 2019 & & \\
\hline $\begin{array}{l}\text { Количество юридических лиц } \\
\text { на конец текущего года, ед. }\end{array}$ & 1945 & 1720 & 1677 & 1609 & 1584 & 82,7 \\
\hline $\begin{array}{l}\text { Списочная численность работников } \\
\text { организаций, чел. }\end{array}$ & 875996 & 753040 & 724867 & 689965 & 672800 & 78,7 \\
\hline $\begin{array}{l}\text { Номинальная начисленная } \\
\text { среднемесячная заработная плата } \\
\text { работников организаций, руб. }\end{array}$ & 711,2 & 821,2 & 963,3 & 1064,9 & 1070,6 & 149,7 \\
\hline $\begin{array}{l}\text { Выручка от реализации продукции, } \\
\text { товаров, работ, услуг, млн руб. }\end{array}$ & 59071 & 67786 & 78162 & 80696 & 17272 & 136,61 \\
\hline Рентабельность продаж, \% & 6,8 & 8,5 & 7,0 & 7,2 & 6,4 & $+0,4$ п. п. \\
\hline $\begin{array}{l}\text { Рентабельность реализованной } \\
\text { продукции, товаров, работ, услуг, \% }\end{array}$ & 8,2 & 10,4 & 8,6 & 8,8 & 7,8 & +0,6 п. п. \\
\hline $\begin{array}{l}\text { Чистая прибыль, убыток (-), } \\
\text { млн руб. }\end{array}$ & 1032 & 2058 & 292 & 3040 & -2550 & 294,59 \\
\hline $\begin{array}{l}\text { Удельный вес убыточных } \\
\text { организаций в общем количестве } \\
\text { обследуемых организаций, \% }\end{array}$ & 25,5 & 19,2 & 19,2 & 15,8 & 25,7 & -9,7 п. п. \\
\hline
\end{tabular}

Источник. URL: belstat.gov.by>upload/iblock/f19/ 
Основные финансовые показатели деятельности организаций в Республике Беларусь, 2016-2020 гг.

\begin{tabular}{|c|c|c|c|c|c|c|}
\hline \multirow{2}{*}{ Показатель } & \multicolumn{4}{|c|}{ Год } & \multirow{2}{*}{$\begin{array}{l}\text { Январь-март } \\
2020 \text { г. }\end{array}$} & \multirow{2}{*}{$\begin{array}{c}2019 \text { г. } \\
\text { к уровню } \\
2016 \text { г., \% } \\
\end{array}$} \\
\hline & 2016 & 2017 & 2018 & 2019 & & \\
\hline $\begin{array}{l}\text { Выручка от реализации } \\
\text { продукции, товаров, работ, } \\
\text { услуг, млн руб. }\end{array}$ & 171298,5 & 192329,7 & 222412,4 & 240149,4 & 59448,9 & 140,2 \\
\hline Рентабельность продаж, \% & 7,3 & 8,2 & 7,6 & 7,0 & 7,4 & $-0,3$ п. П. \\
\hline $\begin{array}{l}\text { Рентабельность реализованной } \\
\text { продукции, товаров, работ, } \\
\text { услуг, \% }\end{array}$ & 9,1 & 10,2 & 9,4 & 8,7 & 9,2 & $-0,4$ п. п. \\
\hline $\begin{array}{l}\text { Чистая прибыль, убыток (-), } \\
\text { млн руб. }\end{array}$ & 4166,4 & 8471,8 & 5821,7 & 10720,8 & $-5820,5$ & 257,3 \\
\hline $\begin{array}{l}\text { Удельный вес убыточных } \\
\text { организаций в общем } \\
\text { количестве обследуемых } \\
\text { организаций, \% }\end{array}$ & 19,2 & 15,3 & 16,0 & 13,1 & 24,2 & -6,1 п. п. \\
\hline
\end{tabular}

Источник. URL: https://www.belstat.gov.by/ofitsialnaya-statistika /publications/ izdania/

заций Республики Беларусь, который позволил сделать следующие выводы (табл. 3): темп роста выручки от реализации составил 40,2\% в 2019 г. к 2016 г., что выше, чем в организациях с государственной долей;

рентабельность продаж и рентабельность реализованной продукции не имеют устойчивой динамики в исследуемых категориях субъектов хозяйствования;

если удельный вес убыточных организаций снизился к концу 2019 г., то за январь-март 2020 г. наблюдается обратная тенденция - рост количества таких субъектов.

Рентабельность является относительным показателем, который характеризует результативность деятельности организаций. Анализ показал, что если в 2017 и 2019 гг. рентабельность продаж и рентабельность реализованной продукции были выше у субъекта хозяйствования с долей государства, то в 2016, 2018 и 2020 гг. эти показатели выше у организаций Республики Беларусь. При этом за 2016-2019 гг. положительные отклонения по показателям составили не более 1,0 п. п. $(0,1-0,9 \%)$, в 2020 г. - -1,4 п. п. по рентабельности реализованной продукции и 1,0 п. п. - рентабельности продаж в пользу организаций Республики Беларусь (табл. 4).

Удельный вес выручки от реализации продукции, товаров, работ и услуг организаций с долей государственной собствен-
Таблица 4

Отклонение показателей рентабельности организаций с долей государства от организаций Республики Беларусь, 2016-2020 гг.

\begin{tabular}{|c|c|c|}
\hline \multirow{2}{*}{ Год } & \multicolumn{2}{|c|}{ Отклонение по показателю, п. П. } \\
\cline { 2 - 3 } & $\begin{array}{c}\text { Рентабельность } \\
\text { продаж }\end{array}$ & $\begin{array}{c}\text { Рентабельность } \\
\text { реализованной } \\
\text { продукции }\end{array}$ \\
\hline 2016 & $-0,5$ & $-0,9$ \\
\hline 2017 & $+0,3$ & $+0,2$ \\
\hline 2018 & $-0,6$ & $-0,8$ \\
\hline 2019 & $+0,2$ & $+0,1$ \\
\hline $\begin{array}{c}\text { Январь-март } \\
2020 \text { г. }\end{array}$ & $-1,0$ & $-1,4$ \\
\hline
\end{tabular}

Источник. URL: https://www.belstat.gov.by/ ofitsialnaya-statistika /publications/ izdania/ URL: belstat.gov.by>upload/iblock/f19/

ности в общей величине выручки организаций Республики Беларусь за 2016-2019 г. находится приблизительно на одинаковом уровне $(33,6-35,25 \%)$. В январе-марте 2020 г. происходит снижение данного показателя до 29,05\% (табл. 5).

Показатели чистой прибыли (убытка) как в организациях с долей государственной собственности, так и в организациях Республики Беларусь характеризуются неустойчивостью. Отмечается значительное снижение в 2018 г. и рост в 2019 г. По результатам I квартала 2020 г. все исследуемые организации получают убытки в размере, сопоставимом с прибылью за 2019 г. Отрицательным моментом является то, что 
Удельный вес выручки от реализации и чистой прибыли (убытка) организаций с долей государства

\begin{tabular}{|c|c|c|c|}
\hline Год & $\begin{array}{c}\text { Удельный вес в общей величине } \\
\text { выручки от реализации организаций } \\
\text { Республики Беларусь, \% }\end{array}$ & $\begin{array}{c}\text { Удельный вес в общей величине } \\
\text { чистой прибыли (убытка) организаций } \\
\text { Республики Беларусь, \% }\end{array}$ & $\begin{array}{c}\text { Отклонение, } \\
\text { п. п. }\end{array}$ \\
\hline 2016 & 34,49 & 24,77 & $-9,72$ \\
\hline 2017 & 35,25 & 24,3 & $-10,95$ \\
\hline 2018 & 35,14 & 5,1 & $-30,04$ \\
\hline 2019 & 33,6 & 28,4 & $-5,2$ \\
\hline $\begin{array}{c}\text { Январь-март } \\
2020\end{array}$ & 29,05 & $-43,9$ & $-72,95$ \\
\hline
\end{tabular}

Источник. URL: https://www.belstat.gov.by/ofitsialnaya-statistika /publications/ izdania/; URL: belstat.gov.by>upload/iblock/f19/

в 2018 г. прибыль от организаций с долей государственной собственности составила только 5\% от всей прибыли организаций страны, а на убытки текущего 2020 г. приходится уже 44\%. Одновременно с этим динамика выручки от реализации не соответствует динамике чистой прибыли (убытка), что привело к финансовой неустойчивости организаций с долей государственной собственности.

Таким образом, в Республике Беларусь создан комплекс правовых, организационных и экономических условий для формирования эффективной системы управления организациями с долей государства. Вместе с тем проведенный анализ деятельности субъектов хозяйствования с долей государственной собственности выявил неустойчивый характер финансовых показателей, наличие убытков и тенденцию роста убыточных организаций. Результаты производственно-экономической и финансовой деятельности исследуемых субъектов хозяйствования ниже в сравнении с остальными организациями Республики Беларусь. Все это указывает на необходимость выработки направлений по совершенствованию системы управления государственными активами данных организаций. С этой целью нами изучен опыт Российской Федерации и Республики Казахстан.

Правовое поле России также не содержит термина «государственные активы». Чаще всего на практике используется категория «государственная собственность», выступающая необходимым условием для реализации органами исполнительной власти социально-экономических функций на федеративном уровне и уровне субъектов федеративного государства. При этом 85 субъектов России имеют механизм управления акционерными обществами, который обладает определенными региональными особенностями. Государственная собственность включает акционерные общества с государственным участием, государственные корпорации, государственные унитарные предприятия. С точки зрения участия государства в капитале и степени его влияния на управленческие решения акционерные общества группируют следующим образом:

до 100\% капитала принадлежит государству;

государству принадлежит контрольный пакет акций (50\% плюс одна акция);

государству принадлежит «золотая акция»;

государству принадлежит блокирующий пакет акций (25\% плюс одна акция);

государству принадлежит миноритарный пакет акций (менее 25\%).

По исследованиям Центра стратегических разработок, показатель доли участия государства в экономике по выручке крупнейших компаний и без учета сектора бюджетных учреждений в 2018 г. составил порядка $40 \%{ }^{14}$. Однако он существенно различается в зависимости от сектора экономики. Так, в энергетике, транспорте, добыче полезных ископаемых и финансах доля выручки государственных организаций в общей выручке топ-100 компаний близка или превышает $50 \%$ (табл. 6).

Наибольшая доля выручки госкомпаний в выручке топ-100 компаний отрасли

${ }^{14}$ URL: https://strategy.csr.ru/user/pages/researches/ Doklad_effektivnoe_upravlenie_gossobstvennostyu_Web.pdf 
Таблица 6

Отраслевая структура компаний Российский Федерации в зависимости от объемов выручки и степень участия государства, 2018 г.

\begin{tabular}{|l|c|}
\hline \multicolumn{1}{|c|}{ Сектор } & $\begin{array}{c}\text { Степень участия } \\
\text { государства (доля } \\
\text { выручки госкомпаний } \\
\text { в выручке топ-100 } \\
\text { компаний отрасли), \% }\end{array}$ \\
\hline Транспорт & 83,0 \\
\hline Энергетика & 70,9 \\
\hline Добыча полезных ископаемых & 70,0 \\
\hline Финансы и страхование & 46,8 \\
\hline Коммунальное хозяйство & 31,9 \\
\hline Машиностроение, автомобилестроение & 30,9 \\
\hline Информатизация и связь, медиа & 22,7 \\
\hline Строительство и стройматериалы & 18,4 \\
\hline Коммерческая недвижимость & 15,9 \\
\hline Образование* & 11,8 \\
\hline Здравоохранение* & 11,5 \\
\hline Химическая промышленность & 9,3 \\
\hline Консультационные, юридические & 8,5 \\
и прочие услуги, охрана & 6,7 \\
\hline Гостиничные услуги и общественное & 4,9 \\
\hline питание & \\
\hline Прочее** & 1,3 \\
\hline Металлургия, металлоизделия & 3,5 \\
\hline и добыча металлических руд & 2,6 \\
\hline Культура, искусство, спорт, лотереи* & 1,0 \\
\hline Фармацевтика & \\
\hline Лес и деревообрабатывающая & \\
промышленность & \\
\hline Торговля & \\
\hline АПК и пищевая промышленность & \\
\hline Легкая промышленность & \\
\hline
\end{tabular}

* Без учета сектора бюджетных учреждений.

** Включая некорректные ОКВЭД, фактически относящиеся к иным группам.

Источник. URL: https://strategy.csr.ru/user/pages/researches/ Doklad_effektivnoe_upravlenie_gossobstvennostyu_Web.

принадлежит транспорту (83\%). Второе место практически делят энергетика и добыча полезных ископаемых (соответственно, 70,9\% и 70\%). Это стратегически значимые отрасли, поэтому высокая степень участия в них государства обоснована. Остальные госкомпании занимают менее $50 \%$ в выручке топ-100 компаний отрасли.

Понятие «государственная корпорация» определено в Федеральном Законе «О некоммерческих организациях» и рассматривается как не имеющая членства некоммерческая организация, учрежденная государством на основании имущественно- го взноса, а также созданная для выполнения социальных, управленческих или других общественных функций ${ }^{15}$. Государственной может считаться корпорация, акционером которой является государство. При этом государственный пакет акций в ней может быть 100\% и менее. Такой субъект хозяйствования реализует значимые социальноэкономические задачи, поставленные правительством страны.

Государственный пакет акций, вложенный в государственную корпорацию, является материальной основой обеспечения деятельности государства и одновременно инструментом государственного регулирования экономики, обеспечивающим реализацию государственной экономической политики. В связи с этим государственные корпорации в Российской Федерации классифицируют на три типа:

созданные для эффективного использования бюджетных средств (например, ГК «Фонд поддержки ЖКХ», ГК «Роснанотехнологии»);

объединяющие стратегически значимые активы (в частности, ГК «Ростехнологии»);

призванные реализовывать задачи в финансовой и банковской сферах (например, ГК «Агентство по страхованию вкладов»).

Государственное унитарное предприятие предполагает закрепление государственного имущества на правах хозяйственного ведения и отчисляет определенный процент прибыли в соответствующий бюджет. Данный вид организационно-правовой формы в контексте государственных активов нами рассматриваться не будет.

На практике управление в акционерных обществах и государственных корпорациях представлено системой корпоративного управления. Так, в Совете директоров

${ }^{15}$ URL: http://www.consultant.ru/document/cons_doc_ LAW_8824/ 
участвуют не только акционеры, избираются также представители государства и независимые директора. Одновременно с этим институт представителей государства обуславливает наличие двух ролей:

регулятор - выполняет реализацию социально-экономической политики;

акционер - заинтересован в росте своих доходов (дивидендов и прироста рыночной стоимости государственного пакета акций). Система, аналогичная владельческому надзору в Республике Беларусь.

В то же время в российской практике управления государственными пакетами акций отмечается тенденция смещения ролей «государство-акционер» и «государстворегулятор». Еще одной особенностью выступает максимизация представителей государства в Совете директоров, что не всегда дает возможность принять решение, отличное от позиции органа государственного управления.

В свою очередь, задачами управления государственными активами в Республике Казахстан являются:

создание единой базы учета государственных активов;

внедрение принципов корпоративного управления;

анализ и оценка системы управления национальными холдингами, акционерными обществами с государственной долей, государственными предприятиями и учреждениями.

Аналогично российским государственным корпорациям в Республике Казахстан появились национальные холдинги, созданные для интеграции в единое образование акционерных обществ с контрольным пакетом акций (долей) государства. Так, функционирует государственный холдинг «Казахстанский холдинг по управлению государственными активами «Самрук»». В хозяйственное ведение данного субъекта входят стратегически значимые и крупные национальные компании страны, в отношении которых через советы директоров используется корпоративное управление ${ }^{16}$.

Выполненные нами исследования показали, что из практики управления государственными активами в России и Казахстане могут быть использованы в Респуб- лике Беларусь определенные механизмы. Во-первых, это консолидация государственных активов путем создания государственных корпораций, обеспечивающих управление в стратегически значимых отраслях. Во-вторых, это развитие института независимых директоров и их обязательное введение в советы директоров (наблюдательные советы) акционерных обществ. Система корпоративного управления акционерными обществами с государственным участием, основанная на рыночных механизмах управления государственными активами, позволит сделать их более доходными и инвестиционно привлекательными. И выиграют от этого бюджет, а также работники и частные акционеры. В-третьих, отметим активное внедрение корпоративного управления, базирующегося на руководящих принципах Организации экономического сотрудничества и развития по корпоративному управлению на государственных предприятиях, включающих прозрачность и ответственность, а также профессионализм и эффективность ${ }^{17}$.

Выполненные нами исследования управленческих аспектов функционирования государственных активов позволяют сделать следующие выводы:

- в настоящее время понятие «государственные активы» отсутствует в законодательстве Республики Беларусь. В теории и практике данный термин используется как обобщающая категория, где государство выступает в качестве предпринимателя и владельца акционерной и долевой собственности;

- экономический анализ за 20162020 гг. показал, что эффективность организаций с долей государственной собственности ниже, чем других субъектов хозяйствования Республики Беларусь. Основными методами управления являются владельческий надзор и корпоративное управление. При этом последний пока внедряется медленно и не дает должных ре-

16 URL: https://www.zakon.kz/203414-pravovojjrezhim-gosudarstvennykh.html

17 Руководящие принципы ОЭСР по корпоративному управлению на государственных предприятиях. URL: https:// www.oecd.org/daf/corporate/principles 
зультатов по повышению эффективности деятельности акционерных обществ;

- установлено, что управление государственными активами в России и Казахстане имеет общие черты. Так, на основе стратегически значимых для экономики и отраслей государственных активов этих стран создаются государственные корпорации и национальные холдинги. В акционерных обществах с государственным участием реализуется корпоративное управление. Практика России показывает, что не всегда удается принимать рациональное решение в интересах государства-акционера и эффективного предпринимателя. В экономике наблюдаются не только подъемы, но и спады, где реализация социально значимых задач выходит на первый план, и именно в этот период государственные активы рассматриваются как инструмент регулирования национальной экономики;

- наиболее действенными мерами по повышению эффективности управления государственными активами Республики Беларусь на основе зарубежного опыта должны стать: создание благоприятных организационно-экономических условий функционирования национальной экономики; совершенствование законодательной базы по предмету исследования; консолидация государственных активов путем создания государственных корпораций; создание института независимых директоров; внедрение практики корпоративного управления. В целом предлагаемые направления должны учитывать национальные приоритеты республики и предусматривать механизмы развития конкурентоспособной экономики страны.

\section{СПИСОК ЛИТЕРАТУРЫ (REFERENCES)}

Аверченко Л., Баранова И. 2014. Методический подход к интегральной оценке эффективности управления государственным имуществом в промышленных холдингах с преобладающим участием государства. Сибирская финансовая школа. № 3. С. 35-39. [Averchenko L., Baranova I. 2014. Methodical approach to integrated assessment of management effectiveness of the state property in the industrial holdings with prevailing participation of the state. Sibirskaya finansovaya shkola. No 3. PP. 35-39. (In Russ.)]

Бадирова A.B. 2012. Анализ создания государственных корпораций в России. Основы экономики, управления и права. № 5. С. 53-56. [Badirova A.V. 2012. Analysis of creation of state corporations in Russia. Osnovy ekonomiki, upravleniya i prava. No 5. PP. 53-56. (In Russ.)]

Бельский В.И. 2018. Экономический механизм государственного регулирования сельскохозяйственного производства: теория, методология, практика. Минск: Институт системных исследований в АПК НАН Беларуси. [Bel'skiy V.I. 2018. The economic mechanism of state regulation of agricultural production: theory, methodology, practice. Minsk: Institut sistemnykh issledovaniy v APK NAN Belarusi. (In Russ.)]

Запорожан А. 2008. Управление пакетами акций, входящими в состав государственной собственности. Управленческое консультирование. Актуальные проблемь государственного и муниципального управления. № 1. С. 136-144. [Zaporozhan A. 2008. Management of blocks of shares as a part of state property. Upravlencheskoe konsul'tirovanie. Aktual'nye problemy gosudarstvennogo i municipal'nogo upravleniya. No 1. PP. 136-144. (In Russ.)]

Ковалев М.М., Румас С.Н., Юшко К.Ю., Шахуб М.Х. 2018. Управление государственным сектором экономики. Минск: Издательский центр БГУ. [Kovalev M.M., Rumas S.N., Yushko K.Yu., Shakhub M.Kh. 2018. Management of public sector of the economy. Minsk: Izdatel'skiy tsentr BGU. (In Russ.)]

Лященко В. 2001. Акционерные общества в российской экономике. Москва: Издательский дом «Новый век». [Lyashchenko V. 2001. Joint Stock Companies in the Russian Economy. Moscow: Izdatel'skiy dom «Novyy vek». (In Russ.)]

Макарова О.А. 2016. Ажционерные общества с государственным участием. Проблемь корпоративного управления. Москва: Юрайт. [Makarova O.А. 2016. Joint-stock companies with state participation. Corporate governance issues. Moscow: Yurayt. (In Russ.)]

Михайленко Д.А. 2014. Некоторые аспекты экономического содержания государственной собственности. Научное обозрение. № 8. С. 274-279. [Mikhaylenko D.A. 2014. Certain aspects of economic content of state property. Nauchnoe obozrenie. No 8. PP. 274-279. (In Russ.)]

Осипенко О. 2016. Управление акционерным обществом в условиях реформы корпоративного nрава. Москва: Статут. [Osipenko O. 2016. Management of Joint-stock company under company law reform. Moscow: Statut. (In Russ.)]

Ташкулова Г. 2014. Зарубежный опыт управления государственными активами. Наука $u$ новые технологии. № 1. С. 132-135. [Tashkulova G. 2014. Foreign experience of management of state assets. Nauka i nooye tekhnologii. No 1. PP. 132135. (In Russ.)] 
In citation: Belorusskiy Economicheskiy zhurnal. 2020. No 3. PP. 47-57.

Belarusian Economic Journal. 2020. No 3. PP. 47-57.

\title{
MANAGEMENT ASPECTS OF THE FUNCTIONING OF STATE ASSETS
}

\section{Svetlana Ryabova ${ }^{1}$}

\begin{abstract}
Authors affiliation: ${ }^{1}$ Academy of Public Administration under the aegis of the President of the Republic of Belarus (Minsk, Belarus).

Corresponding author: Svetlana Ryabova (s-6093981@yandex.ru).

ABSTRACT. The article considers the nature and composition of state assets basically shaped under converting of state unitary enterprises into open joint stock companies. Typologization and target setting for the creation of state corporations and national holdings are given. The system of managing state blocks of shares based on ownership in the Republic of Belarus is analyzed and the characteristic features of state participation through its representative in the management of a joint stock company are substantiated. The experience of the Republic of Kazakhstan and the Russian Federation in the creation of national holdings, the development of corporate relations and their influence on the economy of a business entity is summarized. Based on international experience the study states topical issues of managing state assets in the Republic of Belarus and provides valuable insights and recommendations.
\end{abstract}

KEYWORDS: ownership supervision, state assets, state corporations, corporate governance, national holding, state shareholding, state representative.

JEL-code: H13, H82.

DOI: $10.46782 / 1818-4510-2020-3-47-57$

Received 10.06.2020 